\title{
PIONEER
}

VOLUME 10, Issue 2, December 2018: 156 - 169

\section{AN ANALYSIS OF CONNOTATIVE MEANING ON JUSTIN BIEBER'S SONG LYRICS}

\author{
Ita Purnamasari \\ University of Abdurachman Saleh Situbondo \\ ithapurnamasari953@gmail.com
}

\begin{abstract}
Semantics is the study of the meaning of words, phrases and sentences. Connotative meaning can be found in literary work including song lyrics. A song can also become a media to introduce social values. In this study, the researcher focus on connotative meaning using Chaer's (2013) theory and sense a values of American people using theory by Khols (1984). The data source in this study are Justin Bieber's song lyrics. This research was done by analyzing the data qualitatively. Techniques of data collection are done by downloading the song and the lyrics, listening the song, reading the lyrics and watching the videos. Data analysis was done by adapting Miles and Huberman's theory (1984). The step of data analysis are: reduction of data, display of data, verification of data and conclusion. The result of the research describe words contain connotative meaning and values of American people. The total of data contain connotative meaning are sixteen, six words include in equality/egalitarianism Americans values, four words include in material/acquisitiveness American values, one word include in time and its control American values, three words include in change American values and one word include in self-help concept American values.
\end{abstract}

Keywords : Semantics, connotative meaning, kind of values of American

\section{INTRODUCTION}

Today songs have become parts of life of human. Song is composed by the art of tones or sounds in sequence, combination, and a temporal relationship (usually accompanied by musical insstruments) to produce a piece of music that has unity and continuity (containings cadence). Jamalus opines (1998:1), music is a result of the work of art in the form of sound in form of songs or compositions that express thought and the feeling of creation through the principal elements of music. The opine explained that music is a work of art in the form of sound in the form of a song or compositions that expresses ideas and feelings of his creator through the basic elements of music is rhythm, melody, harmony, and form or structure of the song and expression as a source of unity. Basically the art of music based on the existence of a lyric and rhythm complement to the music. Usually to make a song interesting, the lyrics of the song are made explicit and implicit meaning. However sometimes the listeners of the song and the readers of the lyrics have different opinion about the meaning of the song. 
Semantic is one of a branch of Linguistics which studies meaning. According Kreidler (1998:3). Semantic is the systematic study of meaning, and linguistic semantic is the study how language organize and express meaning. Based on the types of semantic, can be distinguished based on lexical meaning and grammatical meaning. Based on whether there is a value of the sense, a word can be distinguished into denotative and connotative meaning. The relation between words and meaning indeed is arbitrary, there is no mandatory relationship between the rows of phonemes forming the word with its meaning. However, there is an agreement in a group of society if a word can get meaning of it. When words have a meaning from a agreement of society, the relationship between words and meaning cannot change, except if the development of culture and society changes.

According to Chaer (2013:65), a word is called to have a connotative meaning if the word has a "sense of values", both positive and negative. If it does not have a sense of value then it is said to have no connotation, but it can also be called a neutral connotation. Connotative meaning is different from another meaning, because this type of meaning arises due to the association of the feeling of language usage of the word that is heard or read. Connotative meaning is related to value of the sense of people who use language, whether they feel happy, sad, repugnant and angry. Thus positive meaning and negative meaning depend on the sentences. For now, the value of a sense can differences depend on place, time and mean. Positive and negative value of a word often also occurred a result of used that word as a symbolism. So, if people suggest a word of "fire" have a positive value, so the meaning is will be positive value. Different from connotative meaning, denotative meaning gives the meaning according to what it is (the original meaning), but there is no value of the sense, like tall and thin. For denotative meaning, the meaning of the word tall and thin show the size of human's body, but on connotative meaning, the word tall can have a positive meaning because tall can mean so interesting to see, especially for body of men,but italso has a negative meaning if tall means a social status or power.

Study of song has been done by a number of scholars. Abidardah (2010), in his study entitled "A Connotative Meaning Analysis on the Word Child in Five Lyrics of Songs" discussed kinds of the child connotative meaning in five lyric of songs. He selected five songs from different singers but the songs contained about child. One of the song is When the Children Cry by White Lion. He also used theory of Semiotics and look at the condition and history of where the song it released to determined connotative meaning.

Armawansyah (2016), his study entitled "An Analysis of Connotative Meaning in Selected Maher Zain's Songs Lyrics" analyzed connotative meanings and messages on songs. 
In addition, on Maher Zain's song also contains social values, which describe his own feeling. Example song is Palestine Will be Free. This songs describes about the confidence of someone who never desperate. Moreover, Zulaichah (2008), on the titled "Connotative and Denotative Meaning on the lyrics of Tina Arena's Songs" she focussed ind Lexical Meaning the used of Connotative and Denotative meaning are dominant.

However, in the present study the researcher examined the connotative and denotative meaning which dominated in the songs . The differences between this study with the previous research was the object of the study. On Abidarda, he selected song lyrics by White Lion's, Armawasah selected song lyrics by Maher Zain's, and Zulaichah selected song lyrics by Tina Arena's. On the other hand, this study analysed song lyrics by Justin Bieber.

From the previous explanation, the researcher was certain to analyze connotative meaning on lyrics of songs. The researcher selected song lyrics because song was one of types of art work most audience in the world. Each song contained elements of explicit and implicit meaning. In addition, the researcher selected song lyrics of Justin Bieber as the object of research because his song were so populer. People in the world also knew and liked the songs. The selection the of song lyrics on Justin Bieber's was because the researcher wanted people, especially fans of Bieber to know that many words could have connotative meanings and knows what are sense of values. The researcher chose five songs on Purpose album by Bieber, they were What Do You Mean, Sorry, The Feeling, Company and Purpose. These songs were chosen because the video clips were already made. The researcher chose Purpose album because this album was the fastest to be sold out and as the fastest album sales in history from other albums of Bieber.

\section{REVIEW OF LITERATURE}

\section{Semantics}

Semantics is one of a branch of Linguistics which study meaning. In Linguistics, according to Yule (1996:114), Semantics is the study of the meaning of words, phrases and sentences. According to Kreidler (2002:3), Semantics is the systematic study of meaning, and Linguistic Semantic is the study how language organize and express meaning. Hurford and Heasely (2007:1) say that, Semantics is the study of meaning in language. In other word, Semantics is the study of meanings in word, phrases, and sentences to understand the text. 


\section{Connotative Meanings}

According to Chaer (2013:65), a word is called to have a connotative meaning if the word has a "sense of values", both positive and negative. If it does not have a sense of value then it is said to have no connotation, but it can also be called a neutral connotation. Connotative meaning can also change from time to time, because connotative meaning is related to value of the sense of people, and the value of people are different. Connotation vary according to the experience of individuals, but because people do have common experiences, some words have shared connotations (Kreidler, 2002:45 ). For example, the word of "barked". If one says that the "dog barked", the connotative is neutral, but if someone said "my boss often barked to me" the connotation is clearly negative. Because for the general, the word barking is used for dogs, not humans.

\section{Values of Americans.}

Kohls (1984) divides values of American into some types:

\section{Personal Control over the Environment}

Americans no longer believe in the power of fate, and they have come to look at people who do as being backward, primitive, or hopelessly naive.

Example: American people think to believe that Man, and not Fate, can and should be the one who controls the environment, this has made them very good at planning and executing shortterm projects.

\section{Change}

In the American mind, change is seen as an indisputably good condition. Change is strongly linked to development, improvement, progress, and growth.

Example: American people always to do something to make themselves be better, like hard work to get good position in their job.

\section{Time and its Control}

Time is, for the average American, of utmost importance.

Example: American people think, time is money.

\section{Equality/Egalitarianism}

Equality is, for Americans, one of their most cherished values. This concept is so important for Americans that they have even given it a religious basis.

Example: American people belief, who are you, from who you birth, what your job and your position. God views all humans alike. 


\section{Individualism and Privacy}

Each individual is seen as completely and marvelously unique, that is, totally different from all other individuals and, therefore, particularly precious and wonderful. privacy is not only seen as a very positive condition, but it is also viewed as a requirement which all humans would find equally necessary, desirable and satisfying.

Example: American people believe, if they are just a little unique, just a little special, from other members of the same group. And they tend to leave groups as easily as they enter them.

\section{Self-Help Concept}

In the United States, a person can take credit only for what he or she has accomplished by himself or herself.

Example: American people more be pride if can be success with themselves hard work than success because generation.

\section{Competition and Free Enterprise}

Americans believe that competition brings out the best in any individual. They assert that it challenges or forces each person to produce the very best that is humanly possible.

Example: American people feel competitive economy will bring out the best in its people and ultimately. If you look for it, you will see evidence in all areas even in fieldsb as diverse as medicine, the arts, education, and sports that free enterprise is the approach most often preferred in America.

\section{Future Orientation}

Valuing the future and the improvements Americans are sure the future will bring means that they devalue the past and are, to a large extent, unconscious of the present.

Example: American believe if future will bring happiness.

\section{Action/Work Orientation}

"Don't just stand there," goes a typical bit of American advice, "do something!" This expression is normally used in a crisis situation, yet, in a sense, it describes most Americans' entire waking life, where action -- any action -- is seen to be superior to inaction.

Example: American people have schedule in everyday, like Monday until Friday at time to school or work and weekend to go to vacation.

\section{Informality}

If you come from a more formal society, you will likely find Americans to be extremely informal, and you will probably feel, even disrespectful of those in authority.

Example: American bosses often urge their employees to call them by their first names and even feel uncomfortable if they are called by the title "Mr." or "Mrs." 


\section{Directness, Openness and Honesty}

Many other countries have developed subtle, sometimes highly ritualistic, ways of informing other people of unpleasant information. Americans, however, have always preferred the direct approach. They are likely to be completely honest in delivering their negative evaluations. If you come from a society which uses the indirect manner of conveying bad news or uncomplimentary evaluations, you will be shocked at Americans' bluntness.

Example: When boy American like a girl, he will direct said love.

\section{Practicality and Efficiency}

The practical consideration is likely to be given highest priority in making any important decision in the United States. Americans pride themselves in not being very philosophically or theoretically oriented.

Example: American people so like practical thing. Like when they offered to join party, they likely to ask in their practical pursuit, not such questions as: Will it be enjoyable?

\section{Materialism/Acquisitions}

Americans would like to think that their material objects are just the natural benefits which always result from hard work and serious intent - a reward, they think, which all people could enjoy were they as industrious and hardworking as Americans.

Example: American people like to obtaining their material, likes a car, one or more color television sets, an electric hair dryer, an electronic calculator, a tape recorder and a record player, a clothes-washer and dryer, a vacuum cleaner, a powered lawn mower (for cutting grass), a refrigerator, a stove and a dish-washer.

\section{Songs, Music, and Lyrics}

Based on Oxford Learner's Pocket Dictionary (2008:423) song is short piece of music with words that you sing. So that, song with music is different. Jamalus opines (1998:1), music is a result of the work of art in the form of sound in form of songs or compositions that express thought and the feeling of creation through the principal elements of music. Thus, music is sound which contains rhythm. There are some genres of music are pop, jazz, dangdut, rock, blues, classic, etc. Whereas song is piece of music and contain lyrics to singing. Lyrics is a piece of song which contain words or sentences which contain messages to listeners.

\section{METHOD}

Qualitative research is the method which emphasizes more on the aspects of understanding in depth of a problem because this method is more like using the technique of 
analysis, so the understanding to the problem of researched must be very deep. According to menurut Bogdan and Taylor (1975) inMoleong book (2004:3) qualitative method as a research procedure that produces descriptive data in the form words or behaviour that can be observed. This research used descriptive qualitative research because this research described connotative meanings on Justin Bieber's song lyrics.

In this research the data source was Justin Biber's song in Purpose album. The researcher chose five songs, that were What Do You Mean, Sorry, The Feeling, Company and Purpose. The data for this research were in the form of words and sentences on Justin Bieber's song lyrics. In this research, the researcher made herself and a table of data analysis as instrument to find the connotative meanings and to determine a value of a sense on songs lyrics of Justin Bieber.

In techniques of data collection, the researcher did several steps: first, downloading the songs and the lyrics from internet. Second, listening to the songs, reading the lyrics and also watching the videos to find connotative meanings. Third, choosing the words or sentences which contain connotative meaning in the lyrics with a way bold words or sentences that contain connotative meanings. In techniques of data analysis, the researcher used techniques of data analysis adapted from Miles and Huberman (1984). First, reduction of the data. The researcher classified the words or sentences which contained connotative meaning based on their positive or negative values. Second, display of the data. Here the researcher arranged the classified data in Table 3.2. then, the researcher also explained the positive or negative values of the data. Third, verification of the data. In this stage, the researcher reviewed the results of data display by doing triangulation. The researcher refered to Chaer's and Kohls's theory on connotative meaning and its senses. Fourth, conclusion. Here the researcher concluded the analysis by giving a brief justification of the research's result on Justin Bieber's song lyrics.

\section{FINDINGS AND DISCUSSION}

\section{Findings}

This section presents the data of connotative meanings found in song lyrics of Jutin Bieber. There were six teen data found by researcher. The data found were: six words contained connotative meanings in Company song, three in Purpose song, three in Sorry song, one in The Feeling song and three in What do You Mean song. An easier classification can be seen on Table 1 and Table 2. 
Table 1. Classification of Data

\begin{tabular}{llccc}
\hline No & \multirow{2}{*}{ Song Titles } & Total & \multicolumn{2}{c}{ Sense of values } \\
\cline { 3 - 5 } & & 6 & 5 & Positive \\
\hline 1 & Company & 3 & 3 & Negative \\
\hline 2 & Purpose & 3 & 2 & 1 \\
\hline 3 & Sorry & 1 & 1 & 2 \\
\hline 4 & The Feeling & 3 & 1 & \\
\hline 5 & What do You Mean & & & \\
\hline
\end{tabular}

Table 2. Classification of Values

\begin{tabular}{|c|c|c|c|}
\hline No & Song titles & Kind of American values & Total \\
\hline \multirow{3}{*}{1} & \multirow{3}{*}{ Company } & Equality/Egalitarianism & 1 \\
\hline & & Material/acquisitiveness & 4 \\
\hline & & Change & 1 \\
\hline 2 & Purpose & Equality/Egalitarianism & 3 \\
\hline \multirow{2}{*}{3} & \multirow{2}{*}{ Sorry } & Time and its Control & 1 \\
\hline & & Change & 2 \\
\hline 4 & The Feeling & Equality/Egalitarianism & 1 \\
\hline \multirow{3}{*}{5} & \multirow{3}{*}{ What Do You Mean? } & Self-help concept & 1 \\
\hline & & Change & 1 \\
\hline & & Equality/Egalitarianism & 1 \\
\hline
\end{tabular}

\section{Examples of data:}

1. Values: Material/acquisitiveness of American

Song title: Company

Let's set each other's lonely nights

Be each other's paradise

Need a picture for my frame

Someone to share my ring

Tell me what you wanna drinks

I tell you what I got in mind

Oh I don't know your name

But I feel like that's gonna change

This stanza consists of eight lines. In line three, the researcher used the word of picture as data. The word picture has a positive value because it is included in material/ acquisitiveness of American values. American people think if they want materials, they must be obtained. In general, picture is a form of paint, photograph or scene. Based the on lyric, picture here means the complement. Thus, Justin uses the word picture to show if the he needs the girl and he wants to get her as a complement of his life, like a frame needs a picture to make a perfect look. 
2. Values : Change of American

Song title : Company

It ain't about the complications

I'm all about the elevation

We can keep it goin' up

Oh, don't miss out on us

Just wanna have a conversation

Forget about the obligations

Maybe we can stay in touch

Oh that ain't doin' too much

This stanza consists of eight lines. In line two, the word elevation is a datum. The word elevation has a positive value because it is included in change of American value. Americans think if change is a good condition. Based on the lyric and its context, Justin here usesthe word elevation to show if he wants to make a progress for his relationship. He does not want to be the girl's friend, he wants more than being a friend.

3. Values : Equality/Egalitarianism of American

Song title : Purpose

I put my all into your hands

Here's my soul to keep

I let you in with all that I can

You're not hard to reach

And you've blessed me with the best gift

That I've ever known

You give me purpose

Yeah, you've given me purpose

This stanza consists of eight lines. In the first line, the researcher chose hands as a datum. The word hand ha positive value because it is included in equality American value. American people believe if God views all human alike without regarding the differences. In general, hand means a part of body. However, here hands means the power of God. The word of hand is to show a positive good thing, because hands is a tool to give. When you want to give something, you will use your hands. Then, on the lyric context, Justin believes if God knows the best for him. What and like what things in future, he believes God plans everything well. 
4. Values : Time and its Control of American

Song title : Sorry

I'll take every single piece of the blame if you want me to

But you know that there is no innocent one in this game for two

I'll go, I'll go and then you go, you go out and spill the truth

Can we both say the words and forget this?

This stanza consists of five lines. In line two, the researcher picked the word game as a datum. The word game has a positive value because it is included in time and control American value. American people think if time so important, like time is money. In general, game is always associated with an activity that wastes time although it is fun. However, based on the lyric context, the use of the word game here is to show if the relationsip of Justin and his girlfriend is like a game. When he plays a game, he would not always be a winner. It is the aame like their relationship which may have some mistakes that will be disadvantages for the couple.

5. Values : Self-help concept of American

Song title : What do You Mean?

You're so indecisive, what I'm saying

Trying to catch the beat, make up your heart

Don't know if you're happy, or complaining

Don't want for us to end, where do I start?

First you wanna go to the left and you want to turn right

Wanna argue all day, making love all night

First you're up and you're down and then between

Oh I really want to know

What do you mean? Ooh

This stanza consists of nine lines. In line seven, there is the word up as the datum. The word up has a positive value because it is included in self-help concept. American people concept is always about to work hard to get a success even though they are from the class of poor people. In general, there are many explanations about word of up, likes power, ready, and depend on the context. However, here the word up means happy. The use of word up is to show a progress of Justin's girl to be happy from her bad condition, from being hurt 


\section{Discussion}

Based on the result of data analysis, the researcher found the words that have contain connotative meanings and senses of values. Equality/egalitarianism of American values more dominant found on Justin Biber's song because his values is key of life. This values tell about the power of God. Justin Bieber used the values because Justin Biber wants people to have a good relation to God and also to others humans. Equality/egalitarianism of American values included in four songs, they are: Company, Purpose, The Feeling and What do You Mean. In Company song, equality/egalitarianism of American values shows about something given from God of humans, that is paradise. In Purpose song, equality/egalitarianism of American values shows about someone who believe and put all of his life, die, mate and livelihood to God. Meanwhile, in The Feeling song, equality/egalitarianism of American values show about thing beautiful from God for humans, that is heaven, and in What do You Mean song, equality/egalitarianism of American values show about utterance which can be has a positive values if the context show a pastor while give preaching in church. However, here the context show negative values because the utterance does not show equality/egalitarianism of American values.

According to Chabib Thoha (1996: 61), values is essence of attached to something was very important for human life. Thus, values is something which benefit and useful for human as reference to behaviour. The dominant value, that is equality/egalitarianism of American believes that God views all human alike. Therefore, this value is hoped to be an example or life guide for Justin Bieber listeners.

After the researcher found the result of data analysis, the researcher compared the result with the previous results of research. They are Abidardah, Armawansyah, and Zulaichah's research. There were differences between his research to the result of previous research. First, this research was compared with Abidardah's research. The result of his research show about connotative meanings of child the word in five songs. He were chosen song were written in the year 1980's - the first 1990's which was the time when the cold war between Rusia and American happening. He also chosen different group music but same purpose to critic every nation who triggered war. He found some different meaning in the word of child in every songs. Like in song When The Children Cry, in this song the mean of child not child baby. However, show the new and pure way how to govern and the rule government, the new way that course is better than the way that old government has before. He analyzed his research with look at the condition and history of where the song it released 
Second, this research was also compared to Armawansyah's research. The result of his research shows about connotative meanings, messages and also denotation meanings. His data is Maher Zain's songs. His result show the way Maher Zain tells people about ALLAH to moslem. He found many word have messages like word "home" in lyrics song Thanks You Allah, the home it mean back to the right way that Allah bless. Thus, maher zain used the word to tell if Allah always be there, so far we go, we still can go home. He analyzed his research with make a table to determined kinds connotative meanings between positive, neutral and negative, and he found more dominant positive connotation.

The last, this research was compared to Zulaichah research. The result of her research show about denotative and connotative meaning on Tina's songs. She show the differences words contained denotative meaning when the words contained connotative based on the condition in the lyrics. She analyzed her research with found denotative meaning in words which contains connotative meaning. Like in lyric song "keep your heart here with mine" on song title "I Want To Spend My Lifetime Loving You". In denotation, the word keep means cause to remain in a state or position or continue doing something. While, according to connotative meanings, keep means loyalty

\section{CONCLUSIONS AND SUGGESTION}

\section{Conclusion}

Based on the explanation, the first previous study is Abidardah. In his research, he used connotative meaning to described the means of word child in five song. He chosen songs were written in the year 1980's - the first 1990's which was the time when the cold war between Rusia and American happening. His purpose used connotative meaning to show the condition and tell the fell of children when cold war happening. Thus, he want people of word knew if effect of cold war it make public places, school and their home are broken. So, the children fell afraid, sad, and lose confidence. The second previous study is Armawansyah. In his research, he used connotative meaning to described the deep meaning of Maher Zain's songs. He chosen song of Maher Zain because many people was careless of command to Allah. Thus, with his research he want people of moslem more so close and more obedient to Allah. When you putt all of Allah, your life will more be a good and can so ready to waiting dead day.

The last previous study is Zulaichah. In her research, she used connotative and denotative meanings to describe the deep meaning of Tina's songs. She chose Tina's songs because Tina is a diva from her country. Thus, she wants to show people what words contain 
connotative and denotative meaning in every song of Tina's, so that the listeners can understand more the meaning in Tina's every song.

Then, in this research, the researcher used values of American to determine positive and negative sense, and the researcher found the dominant positive senses of values. The dominant positive values show if Bieber want the readers or the listeners if his work can be a good example to make a lyrics song which have connotative meanings. Bibers also show how to chose the good words of connotation in every situation.

Thus, from the explanation previous studies and this research, the use of connotative meaning in songs aims to make listeners not only feel about beautiful music, but also can feel beautiful lyrics. The use of words containing connotative meaning is to express the feeling, thinking and ability of the creator of the song and every words in the lyric can make effects for listeners and readers. Connotative meaning have effect for listeners and people of world, that is the song will be interesting to listen because using poetic words and using style of language. Here Justin Bieber and the song writer include values of American people to introduce the values to people of the world, especially Justin Bieber's listeners.

Based on data and analysis has been obtained by the researcher, it can be concluded that there are connotative meaning and sense of values of American people. The researcher found the words that have contain connotative meanings and senses of values. Equality/egalitarianism of American values more dominant found on Justin Biber's song because his values is key of life. This values tell about the power of God. Justin Bieber used the values because Justin Biber wants people to have a good relation to God and also to others humans. Connotative meaning in Justin Bieber's songs makes the song more interesting. Besides, the connotative meaning makes the lyrics unique and sound poetic. The values of Americans in Justin Bieber's songs here can be used to introduce the values of American to people of the world, especially Justin Bieber's listeners. The positive values can also become examples to Justin bieber's listeners because Justin Bieber has so many fans that he has the power to influence his fans.

\section{Suggestions}

The researcher would like to give some suggestion. For Justin bieber listeners, hoped that they can take and copy positive American values in Justin Bieber's songs. Besides, for song writer to add more kind of positive American values to introduce to the listeners. For future researcher, the result of this research also can be as reference in studying Linguistics, especially about semantics and more specific in connotative meaning. 


\section{REFERENCES}

Abidardah, M. (2010). A Connotative Meaning Analysis on The Word Child. Letters and Humanities Faculty State Islamic University Syarif Hidayatullah Jakarta.

Armawansyah. (2016). An Analysis of Connotative Meaning in Selected Maher Zain'S Songs Lyrics. Letters and Humanities Faculty State Islamic University of Syarif Hidayatullah Jakarta.

Chaer, A. (2013). Pengantar Semantik Bahasa Indonesia. Jakarta: PT Rineka Cipta.

Hurford, H. S. (2007). Semantics A Coursebook Second Edition. NewYork: Cambridge University Press.

jamalus. (1988). Pengajaran Musik melalui Pengalaman. Jakarta: Departemen Pendidikan dan Kebudayaan.

Kohls, L. R. (1984). The Values American Live. Washington: Meridian House International.

Kreidler, C. W. (2002). Introducing English Semantics. NewYork: The Taylor and Francis ELibrary.

Miles Mathew B, H. M. (1984). Qualitative Data Analysis A Sourcebook of New Method. London: Sage Publications.

Murphey, Tim, 1992. Music and song. Oxford: Oxford University Press.

Moleong, L., \& J. (2004). Metode Penelitian Kualitatif. Bandung: Remaja Rosdakarya.

Press, O. U. (2008). Oxford Learner'S Pocket Dictionary Fourth Eedition. NewYork: Oxford University Press.

Thoha, c. (1996). Kapita selekta pendidikan islam. Yogyakarta: Pustaka Pelajar.

Yule, G. (1996). The Study of Language Second edition. NewYork: The Press Syndicate of The University of Cambridge.

Zulaichah, S. (2008). Connotative and Denotative Meanings on the Lyrics of Tina Arena'S Song. English Letters and Language Departement Humanities and Culture Faculty the State Islamic University of Malang. 